\title{
PENGUKURAN TINGKAT KAPABILITAS TATA KELOLA INFRASTRUKTUR TEKNOLOGI INFORMASI MENGGUNAKAN KERANGKA KERJA COBIT 5 dan ITIL V.3 (Studi Kasus: MBS Yogyakarta)
}

\author{
Fachruddin Edi Nugroho Saputro ${ }^{1}$, Wiwik Sariningsih ${ }^{2}$ \\ ${ }^{1}$ Prodi D3 Rekam Medis dan Informasi Kesehatan, Fakultas Ilmu Kesehatan, Universitas Duta Bangsa Surakarta \\ ${ }^{2}$ Prodi S1 Akuntansi, Fakultas Hukum dan Bisnis, Universitas Duta Bangsa Surakarta \\ ${ }^{1}$ fachruddinedi@udb.ac.id, ${ }^{2}$ wiwik sariningsih@udb.ac.id
}

\begin{abstract}
Abstrak
Pengukuran tingkat kapabilitas tata kelola infrastruktur teknologi informasi bertujuan untuk mengetahui tata kelola infrastruktur teknologi informasi di MBS Yogyakarta. Pengukuran tingkat kapabilitas dilakukan dengan menggunakan kerangka kerja COBIT 5. Pengukuran tingkat kapabilitas dilakukan dengan menilai kondisi saat ini dan kondisi harapan. Analisis gap antara kondisi harapan dengan kondisi saat ini digunakan untuk menentukan saran perbaikan dan pengembangan. Hasil rekapitulasi pengukuran tingkat kapabilitas pada domain BAI06 yaitu level 1 mencapai 82,14\%, level 2 mencapai 83,9\%, level 3 mencapai 83,09\%, level 4 mencapai 81,9\%, dan level 5 mencapai 84,77\%. Hasil pengukuran tingkat kapabilitas pada domain BAI06 manage changes berada pada level 1 performed process sedangkan harapan yang ingin dicapai berada pada level 5 optimizing. Berdasarkan pengukuran tersebut terjadi kesenjangan 4 level sehingga perlu dilakukan perbaikan dan pengembangan aspek yang belum dipenuhi. Saran perbaikan dan pengembangan berdasarkan kerangka kerja ITIL V3 antara lain: perlunya dokumentasi petunjuk pengelolaan inovasi teknologi informasi dan perbaikannya untuk mendukung tujuan bisnis, melakukan koordinasi dalam melakukan pengambilan keputusan antar divisi, menerapkan pengelolaan perubahan darurat teknologi informasi.
\end{abstract}

Kata kunci : COBIT 5, ITIL V3, tingkat kapabilitas, tata kelola, teknologi informasi

\begin{abstract}
Measuring the capability level of information technology infrastructure governance aims to determine information technology infrastructure governance in MBS Yogyakarta. Measurement of the level of capability is carried out using the COBIT 5 framework. Capability level measurement is done by assessing current and expected conditions. Gap analysis between the expected condition and the current condition is used to determine suggestions for improvement and development. The results of the recapitulation of the capability level measurement in the BAI06 domain are level 1 reaching $82.14 \%$, level 2 reaching $83.9 \%$, level 3 reaching $83.09 \%$, level 4 reaching $81.9 \%$, and level 5 reaching $84.77 \%$. The measurement results of the capability level in the BAI06 domain manage changes are at level 1 performed process, while the expectations to be achieved are at level 5 optimizing. Based on this measurement, there is a gap of 4 levels so that it is necessary to improve and develop unmet aspects. Suggestions for improvement and development based on the ITIL V3 framework include: the need for documentation of information technology innovation management guidelines and their improvements to support business goals, coordinate in making decisions between divisions, implement information technology emergency change management.
\end{abstract}

Keywords: COBIT 5, ITIL V3, level of capability, governance, information technology

\section{Pendahuluan}

Teknologi informasi saat ini tidak hanya berfungsi sebagai penyedia layanan saja, melainkan diharapkan dapat berperan menjadi partner dalam menentukan strategi bisnis baru (Surendro, 2009). Agar teknologi informasi berjalan secara optimal dalam mendukung strategi bisnis, maka perlu memperhatikan tata kelola teknologi informasi (Surendro, 2009). Pendekatan tata kelola teknologi informasi mengacu kepada tata kelola keuangan, sehingga dalam tata kelola teknologi informasi memastikan adanya penggunaan teknologi informasi untuk menentukan keputusan spesifik dan kerangka kerja organisasi yang akuntabel untuk mengarahkan perilaku yang diinginkan dalam penggunaan teknologi informasi (Weill dan Ross, 2004). Tata kelola teknologi informasi dibutuhkan untuk mendorong transformasi bisnis dalam pencapaian visi, misi dan tujuan organisasi serta teknologi 


\section{Jurnal Teknologi Informasi Dan Komunikasi, ISSN : 2087-0868, Volume}

11 Nomor 2 September 2020, Pengukuran Tingkat Kapabilitas Tata Kelola Infrastruktur Teknologi Informasi Menggunakan Kerangka Kerja COBIT 5 Dan ITIL V.3

informasi membutuhkan tata kelola yang baik agar selaras dengan strategi bisnis dalam mencapai tujuan organisasi (Jogiyanto dan Abdillah, 2011).

MBS (Muhammadiyah Boarding School) merupakan salah satu pondok pesantren yang berada di Yogyakarta dan didirikan pada tanggal 20 januari 2008. MBS (Muhammadiyah Boarding School) menyelenggarakan pendidikan pesantren dengan memadukan kurikulum pendidikan pesantren dan kurikulum pendidikan nasional. Perkembangan bisnis mendorong MBS (Muhammadiyah Boarding School) melakukan pengembangan dari segi pembangunan gedung dan fasilitas untuk mendukung kegiatan belajar mengajar. Dengan semakin berkembangnya fasilitas di Muhammadiyah Boarding School perlunya dukungan dari sumber daya manusia dan infrastruktur teknologi informasi. Di dunia pendidikan, infrastruktur teknologi informasi mempunyai peranan yang penting dalam keberhasilan kegiatan sehari-hari (Riedel et al, 2008). Infrastruktur teknologi informasi merupakan pondasi layanan teknologi informasi karena layanan teknologi informasi tidak akan berjalan semestinya tanpa adanya infrastruktur teknologi informasi (Fryonanda, 2017). Paradigma infrastruktur saat ini tidak hanya terfokus kepada hardware tetapi sudah mencakup software (Robertson dan Slibar, 2001).

MBS (Muhammadiyah Boarding School) belum memiliki divisi yang mengelola infrastruktur teknologi informasi secara khusus. Pengelolaan infrastruktur teknologi informasi yang berupa hardware dikelola oleh divisi sarana dan prasarana sedangkan pengelolaan website dan internet dikelola oleh divisi humas. MBS (Muhammadiyah Boarding School) menerapkan sistem pembayaran menggunakan kartu siswa di unit ekonomi pesantren seperti di koperasi, hasbuna mart, kantin, hasbuna resto, tokomu putra, tokomu putri, hasbuna catering, dan hasbuna laundry. Sistem pembayaran menggunakan kartu siswa mengalami kendala ketika adanya pergantian sumber daya manusia. Sumber daya manusia yang menguasai TI dan menangani terkait dengan sistem pembayaran menggunakan kartu siswa mengundurkan diri atau resign dari Muhammadiyah Boarding School. Sistem pembayaran menggunakaan kartu siswa saat ini belum terkelola dengan baik dikarenakan tidak adanya sumber daya manusia yang berlatar belakang TI dan menguasai sistem tersebut. Layanan teknologi informasi yang tidak dikelola dengan baik akan menimbulkan biaya operasional yang sulit diprediksi, layanan yang tidak terkontrol, dan pengambilan keputusan yang kurang tepat (Ali dan Green 2012) dan (Weill dan Ross 2004). Dengan semakin berkembangnya MBS (Muhammadiyah Boarding School) diperlukannya tata kelola infrastruktur teknologi informasi yang baik untuk mendukung visi, misi, dan tujuan organisasi.

Tata kelola teknologi informasi mempunyai peranan yang penting dalam memaksimalkan teknologi informasi yang sudah diimplementasikan oleh organisasi guna menyelaraskan strategi TI dengan strategi bisnis organisasi (Purnomo, Fauziati, dan Winarno, 2016). Dengan adanya tata kelola teknologi informasi di sebuah organisasi diharapkan semua kegiatan bidang teknologi informasi dapat mendukung tercapainya tujuan organisasi tersebut (Anas, Winarno, dan Fatta, 2017). Saat ini tersedia beberapa kerangka kerja tata kelola teknologi informasi dan metode pengukuran untuk mengukur kinerja teknologi informasi di sebuah organisasi (Purnomo, Fauziati, dan Winarno, 2016). Beberapa kerangka kerja dan metode tata kelola teknologi informasi antara lain : Information Technology Infrastructure Library (ITIL), ISO/IEC 17799, Committee of Sponsoring Organization (COSO), dan Control Objective for Information and Related Technology (COBIT) (Purnomo, Fauziati, dan Winarno, 2016). ISO/IEC 17799 merupakan kerangka kerja yang berfokus pada sistem tata kelola keamanan informasi yang memberikan saran terkait dengan keamanan informasi organisasi tetapi masih berdiri sendiri atau tidak terintegrasi dengan rerangka sistem tata kelola teknologi informasi yang lebih luas (Jogiyanto dan Abdillah, 2011). COSO merupakan kerangka kerja yang lebih fokus kepada perbaikan kualitas pelaporan keuangan melalui etika bisnis, dan pengendali internal yang efektif (Purnomo, Fauziati, dan Winarno, 2016).

COBIT 5 digunakan untuk tata kelola teknologi informasi (Retrialisca dan Subriadi, 2017). COBIT 5 menyediakan ukuran, indikator, proses dan kumpulan best practice untuk membantu organisasi mengoptimalkan teknologi informasi dan pengembangan teknologi informasi yang pantas pada organisasi tersebut (Retrialisca dan Subriadi, 2017). COBIT 5 juga digunakan untuk mengukur tingkat kapabilitas dari setiap proses teknologi informasi yang ada (Retrialisca dan Subriadi, 2017). ITIL merupakan kerangka kerja yang menggambarkan best practice dalam manajemen layanan TI. ITIL menyediakan kerangka kerja yang digunakan untuk tata kelola TI dan perbaikan kualitas layanan TI dari sisi bisnis dan perspektif pengguna (Fryonanda, 2017). COBIT dan ITIL memberikan pendekatan terpadu dan top-to-bottom terhadap tata kelola TI dan manajemen layanan dari perspektif bisnis (Simotakis, 2013). COBIT menjelaskan apa yang harus dilakukan dan ITIL menjelaskan secara rinci bagaimana melakukannya serta menyediakan panduan terhadap kegiatan yang harus dilakukan (Van Gembergen, 2004). Perpaduan antara COBIT dan ITIL akan memperkuat dalam 


\section{Jurnal Teknologi Informasi Dan Komunikasi, ISSN : 2087-0868, Volume}

11 Nomor 2 September 2020, Pengukuran Tingkat Kapabilitas Tata Kelola Infrastruktur Teknologi Informasi Menggunakan Kerangka Kerja COBIT 5 Dan ITIL V.3

tata kelola TI dengan kemungkinan yang lebih besar dukungan manajemen dan penggunaan yang lebih efektif dalam penerapan sumber daya (Simotakis, 2013). Pengukuran tingkat kapabilitas penting dilakukan untuk mengetahui berada pada tingkat berapakah tata kelola teknologi informasi yang dijalankan oleh organisasi dan hasil dari pengukuran ini bisa dijadikan acuan untuk perbaikan tata kelola teknologi informasi selanjutnya (Noorhasanah, Winarno, Adhipta, 2015). Tata kelola teknologi informasi merupakan pengelolaan teknologi informasi yang selaras dengan strategi bisnis organisasi yang dilakukan oleh dewan direksi, manajemen eksekutif, dan juga oleh manajemen teknologi informasi (Surendro, 2009).

Pada penelitian ini dilakukan pemilihan domain pada COBIT 5 mengacu kepada IT-related goals yaitu security of information, processing infrastructure and application (ISACA, 2012). Hasil dari pemilihan ini terdapat 5 domain proses yang terkait dengan security of information, processing infrastructure and application yaitu EDM03 (ensure risk optimization), AP012 (manage risk), APO13 (manage security), BAI06 (manage changes), DSS05 (manage security service) (ISACA, 2012). Berdasarkan dari kelima domain proses tersebut BAI06 adalah domain proses yang sesuai dengan permasalahan yang ada di MBS (Muhammadiyah Boarding School). BAI06 (manage changes) mengelola semua perubahan dengan cara yang terkendali, termasuk perubahan standar dan perawatan darurat yang berkaitan dengan proses bisnis, aplikasi, dan infrastruktur (ISACA, 2012). Pemilihan domain pada ITIL V.3 berdasarkan related guidance domain proses BAI06 yaitu service transition pada proses change management (ISACA, 2012).

Dalam case study ini akan dibahas mengenai pengukuran tingkat kapabilitas tata kelola infrastruktur teknologi informasi di MBS (Muhammadiyah Boarding School) Yogyakarta untuk mengetahui tata kelola infrastruktur teknologi informasi yang sudah di jalankan pada saat ini dan disesuaikan dengan kerangka kerja COBIT 5 yang diintegrasikan dengan kerangka kerja ITIL V.3.

\section{Tinjauan Pustaka}

Hartawan dan Suroso (2017) melakukan penelitian terkait dengan information technology service evaluation based ITIL V3 2011 and COBIT 5 in center for data and information. Tujuan dari penelitian ini adalah mengukur kemampuan layanan informasi di Kementrian Pertahanan untuk meningkatkan kepuasan pemangku kepentingan. Hasil dari penelitian ini adalah pengukuran tingkat kapabilitas rata-rata berada pada level 1 pada domain APO09, BAI02, BAI10, DSS01, DSS02, DSS03, DSS04 dan berada level 2 pada domain APO07, APO13, BAI04, BAI08 sedangkan harapannya berada pada level 3 dan level 4 . Peningkatan kemampuan dilakukan secara bertahap dengan meningkatkan area level terkecil terlebih dahulu dan upaya melakukan peningkatan untuk mencapai tujuan dengan memberikan rekomendasi kegiatan dalam bentuk kebijakan dan prosedur manajemen data dan informasi.

Motii dan Semma (2017), melakukan penelitian dengan judul towards a new approach to pooling COBIT 5 and ITIL V3 with ISO/IEC 27002 for better use of ITG in the Moroccan parliament. Tujuan dari penelitian ini yaitu mempelajari pentingnya tata kelola TI (IT Governance) dan mengusulkan pendekatan baru untuk menggabungkan referensi ITIL, COBIT dengan ISO/IEC 27002 untuk penggunaan IT Governance yang lebih baik di parlemen Maroko. Dari penelitian ini saran yang diusulkan adalah desain versi yang mengintegrasikan sebagian besar pembangunan berikutnya pada proses dalam kerangka kerja IT Governance, dan didasarkan pada prinsip-prinsip siklus hidup layanan TI. Siklus hidup layanan TI diusulkan oleh ITIL yang juga digunakan untuk mendefinisikan strategi, konsep, dan proses. COBIT digunakan untuk menilai critical success factor dan ISO/IEC 27002 berkaitan dengan panduan manajemen dan keamanan TI.

\section{Metode}

\subsection{Jenis, Sifat, dan Pendekatan Penelitian}

Jenis penelitian yang dilakukan yaitu penelitian studi kasus yang merupakan penelitian dengan menempatkan obyek atau target penelitian sebagai kasus di dalam penelitian untuk mengungkap keunikan serta kekhasan karakteristik yang terdapat dalam kasus yang diteliti (Stake, 2006). Sifat dari penelitian ini adalah deskriptif yaitu penelitian yang bertujuan untuk mendeskripsikan keadaan atau kejadian yang terjadi tanpa memanipulasi obyek penelitian (Sudaryono, 2015) dengan pendekatan kuantitatif.

\subsection{Metode Pengumpulan Data}

Metode pengumpulan data yang digunakan pada penelitian ini antara lain:

a. Observasi

Observasi dilakukan dengan pengamatan secara langsung terhadap objek penelitian yaitu MBS (Muhammadiyah Boarding School) Yogyakarta untuk mengetahui proses bisnis yang berjalan.

b. Kuesioner 


\section{Jurnal Teknologi Informasi Dan Komunikasi, ISSN : 2087-0868, Volume}

11 Nomor 2 September 2020, Pengukuran Tingkat Kapabilitas Tata Kelola Infrastruktur Teknologi Informasi Menggunakan Kerangka Kerja COBIT 5 Dan ITIL V.3

Kuesioner digunakan sebagai instrumen utama dalam pengumpulan data dengan mengajukan pertanyaan secara tertulis kepada responden untuk menilai tingkat kapabilitas tata kelola infrastruktur teknologi informasi di MBS (Muhammadiyah Boarding School). Pernyataan yang terdapat pada kuesioner berdasarkan pada model kapabilitas proses COBIT 5. Kuesioner menilai dua kondisi yaitu kondisi saat ini dan kondisi yang diharapkan. Skala pengukuran kuesioner menggunakan skala Guttman dengan nilai ya atau tidak.

\subsection{Metode Analisis Data}

Penelitian ini menggunakan teknik analisis data process assessment model (PAM) untuk menilai tingkat kapabilitas tata kelola infrastruktur teknologi informasi. PAM merupakan model pengukuran yang digunakan dalam COBIT 5 untuk menentukan saran berdasarkan Analisis Capability Level dan Analisis Kesenjangan (GAP Analysis) antara kondisi sekarang dengan kondisi yang diharapkan.

\subsection{Alur Penelitian}

Tahapan-tahapan yang dilakukan pada penelitian pengukuran tingkat kapabilitas tata kelola infrastruktur teknologi informasi di MBS (Muhammadiyah Boarding School) dapat dilihat pada gambar 1 .

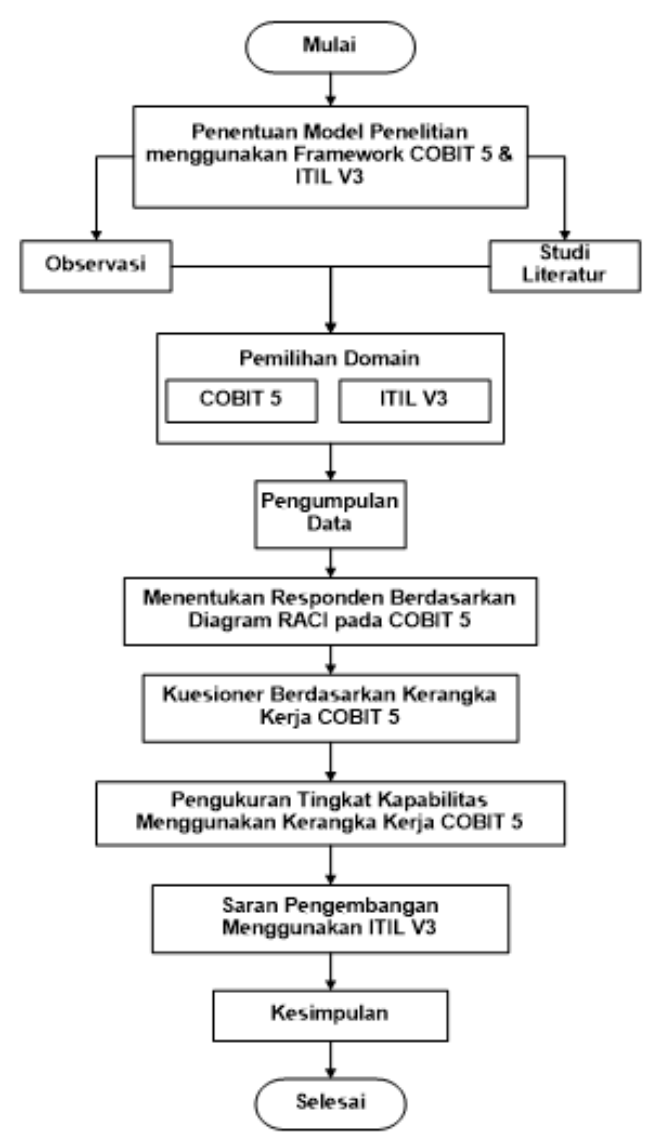

Gambar 1. Alur Penelitian

Keterangan dari alur penelitian yang dilakukan seperti pada gambar 1 adalah sebagai berikut:

a. Studi literatur

Kegiatan pada tahap ini yaitu mempelajari penelitian terdahulu dan buku-buku yang berhubungan dengan tata kelola infrastruktur teknologi informasi serta mempelajari dan memilih metode yang digunakan. Hasil pada tahapan ini adalah tinjauan pustaka dan landasan teori sebagai dasar penelitian ini.

b. Analisis kerangka kerja COBIT 5 dan ITIL V.3

Kegiatan pada tahapan ini adalah analisis kerangka kerja COBIT 5 dan ITIL V.3 terfokus pada tata kelola infrastruktur teknologi informasi serta pengukuran proses berdasarkan kerangka kerja tersebut. Hasil dari tahap ini peneliti menentukan konsep dan domain yang akan digunakan dalam penelitian ini berdasarkan kerangka kerja COBIT 5 dan ITIL v.3.

c. Observasi

Pada tahap ini peneliti melakukan kunjungan serta melakukan pengamatan secara langsung kepada divisi yang bertanggung jawab pada infrastruktur teknologi informasi di MBS (Muhammadiyah Boarding School) Yogyakarta serta mengumpulkan data-data yang diperlukan pada 


\section{Jurnal Teknologi Informasi Dan Komunikasi, ISSN : 2087-0868, Volume}

11 Nomor 2 September 2020, Pengukuran Tingkat Kapabilitas Tata Kelola Infrastruktur

Teknologi Informasi Menggunakan Kerangka Kerja COBIT 5 Dan ITIL V.3

tahap persiapan yang berhubungan dengan tata kelola infrastruktur teknologi informasi.

d. Penyusunan kuesioner dan penentuan responden Berdasarkan konsep yang telah dibuat dan datadata hasil dari tahap observasi, peneliti membuat daftar pernyataan untuk mengumpulkan data yang diperlukan dalam penelitian ini.

e. Pengukuran tingkat kapabilitas

Berdasarkan data yang diperoleh dari kuesioner kemudian dilakukan pengukuran tingkat kapabilitas untuk menjadi dasar dalam memberikan saran kepada MBS (Muhammadiyah Boarding School) Yogyakarta.

f. Saran pengembangan

Pada tahap ini peneliti memberikan saran yang digunakan untuk perbaikan di MBS (Muhammadiyah Boarding School) Yogyakarta terkait dengan tata kelola infrastruktur teknologi informasi.

g. Kesimpulan

Pada tahapan ini peneliti menyimpulkan hasil dari penelitian yang berupa hasil pengukuran tingkat kapabilitas serta saran yang dapat diberikan untuk meningkatkan tata kelola infrastruktur teknologi informasi dengan berdasarkan kerangka kerja COBIT 5 dan ITIL V3.

\section{Hasil dan Pembahasan}

\subsection{Pengukuran Tingkat Kapabiltas Tata Kelola Infrastruktur Teknologi Informasi}

Pengukuran tingkat kapabilitas dilakukan dengan memberikan kuesioner kepada responden di MBS (Muhammadiyah Boarding School) Yogyakarta. Kuesioner ini berisi pernyataan berdasarkankan pada domain BAI06 COBIT 5 pada Capability Level. Responden ditentukan berdasarkan tabel RACI (Responsibility, Accountability, Consult, and Inform) pada domain BAI06 COBIT 5. Penentuan responden berdasarkan RACI Chart dapat dilihat pada tabel 1 berikut ini.

Tabel 1. RACI Chart pada domain BAI06 COBIT 5

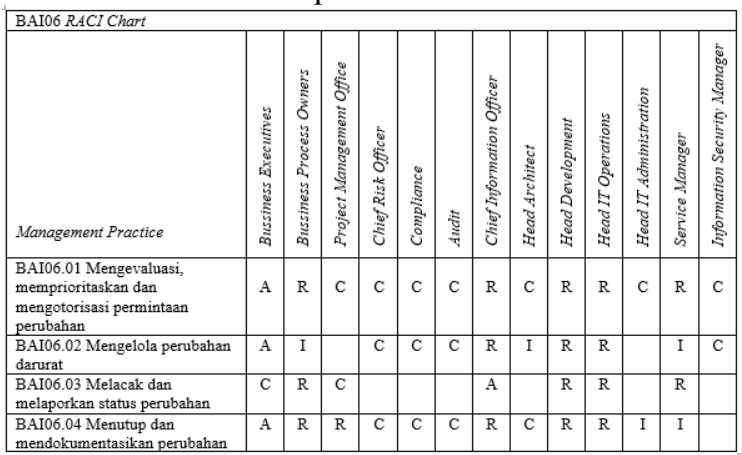

Identifikasi RACI Chart pada domain BAI06 dikonversikan dengan struktur organisasi MBS (Muhammadiyah Boarding School) Yogyakarta yang ditunjukan pada tabel 2. Daftar responden yang telah ditentukan melalui RACI Chart kemudian dilakukan mapping berdasarkan kondisi di MBS (Muhammadiyah Boarding School) Yogyakarta. Daftar responden dan mapping berdasarkan RACI Chart dapat dilihat pada tabel 2 berikut ini.

Tabel 2. Daftar responden kuesioner

\begin{tabular}{|c|l|l|c|}
\hline No & \multicolumn{1}{|c|}{ Mapping RACI Chart } & \multicolumn{1}{c|}{ Responden } & Jumlah \\
\hline 1 & Business Executives & Direktur & 1 \\
\hline 2 & Business Process Owners & Sekretaris Umum & 1 \\
\hline 3 & $\begin{array}{l}\text { Project Management } \\
\text { Office }\end{array}$ & Kepala Bagian Humas & 1 \\
\hline 4 & Chief Information Officer & Kepala Kantor & 1 \\
\hline 5 & Head Development & $\begin{array}{l}\text { Kepala Bagian Sarana dan } \\
\text { Prasarana }\end{array}$ & 1 \\
\hline 6 & Head IT Operations & Kepala Laboratorium Komputer & 1 \\
\hline 7 & Service Manager & Anggota Humas & 1 \\
\hline \multicolumn{2}{|c|}{ Jumlah } & 7 \\
\hline
\end{tabular}

Kuesioner yang diberikan kepada responden berisi pernyataan yang harus dijawab dengan menggunakan skala Guttman yaitu responden menjawab ya atau tidak berdasarkan kuesioner tersebut. Pada setiap satu pernyataan pada kuesioner tersebut terdiri dari pernyataan dari level 0 incomplete process, level 1 performed process, level 2 managed process, level 3 established process, level 4 predictable process, dan level 5 optimising process

Kuesioner yang telah diisi oleh responden kemudian diproses ke dalam metode perhitungan Guttman. Hasil pengolahan dijelaskan sebagai berikut.

a. Jawaban semua responden pada kuesioner berdasarkan kondisi saat ini dijumlahkan atau ditotal.

b. Dihitung persentase dengan cara jumlah jawaban $\mathrm{Y}$ dibagi dengan jumlah pernyataan untuk setiap bagian dikalikan $100 \%$.

c. Selanjutnya persesntase yang diperoleh masuk kategori $\mathrm{N}, \mathrm{P}, \mathrm{L}$, atau $\mathrm{F}$ berdasarkan rating levels pada Tabel 3 berikut ini.

Tabel 3. Rating Levels

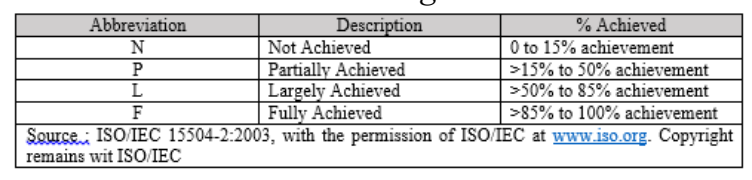

Berdasarkan hasil dari kuesioner yang diisi oleh responden diperoleh pengukuran atribut level $1,2,3,4$, dan 5 pada domain BAI06 (manage changes). Pengukuran atribut level 1 pada domain BAI06 dapat dilihat pada tabel 4 berikut ini.

Tabel 4. Pengukuran atribut level 1 domain BAI06

\begin{tabular}{|c|c|c|c|c|c|c|c|c|c|}
\hline \multirow[t]{2}{*}{ No } & \multirow{2}{*}{ Aspek } & \multicolumn{7}{|c|}{ Responden } & \multirow{2}{*}{ Persentase } \\
\hline & & 1 & 2 & 3 & 4 & 5 & 6 & 7 & \\
\hline 1 & $\begin{array}{l}\text { PA 1.1.1 Mengevaluasi, } \\
\text { memprioritaskan dan mengotorisasi } \\
\text { permintaan perubahaan }\end{array}$ & $\mathrm{Y}$ & $\mathrm{Y}$ & T & $\mathrm{Y}$ & $\mathrm{Y}$ & $\mathrm{Y}$ & $\mathrm{Y}$ & $85,71 \%$ \\
\hline 2 & $\begin{array}{l}\text { PA 1.1.2 Mengelola perubahan } \\
\text { darurat }\end{array}$ & $\mathrm{Y}$ & $\mathrm{T}$ & $\mathrm{T}$ & $\mathrm{Y}$ & $\mathrm{Y}$ & $\mathrm{Y}$ & $\mathrm{Y}$ & $71,43 \%$ \\
\hline 3 & $\begin{array}{l}\text { PA 1.1.3 Melacak dan melaporkan } \\
\text { status laporan perubahan }\end{array}$ & $\mathrm{Y}$ & $\mathrm{Y}$ & $\mathrm{T}$ & $\mathrm{Y}$ & $\mathrm{Y}$ & $\mathrm{Y}$ & $\mathrm{Y}$ & $85,71 \%$ \\
\hline 4 & $\begin{array}{l}\text { PA 1.1.4 Menutup dan } \\
\text { mendokumentasikan perubahan }\end{array}$ & $\mathrm{Y}$ & $\mathrm{T}$ & $\mathrm{Y}$ & $\mathrm{Y}$ & $\mathrm{Y}$ & $\mathrm{Y}$ & $\mathrm{Y}$ & $85,71 \%$ \\
\hline
\end{tabular}

Rata-rata pencapaian pengukuran atribut level 1 pada domain BAI06 adalah 82,14\%. Berdasarkan 


\section{Jurnal Teknologi Informasi Dan Komunikasi, ISSN : 2087-0868, Volume}

11 Nomor 2 September 2020, Pengukuran Tingkat Kapabilitas Tata Kelola Infrastruktur Teknologi Informasi Menggunakan Kerangka Kerja COBIT 5 Dan ITIL V.3

rating levels pada tabel 3 level 1 pada domain BAI06 termasuk dalam pencapaian L (Largely Achieved).

Tabel 5. Pengukuran atribut level 2 pada domain BAI06

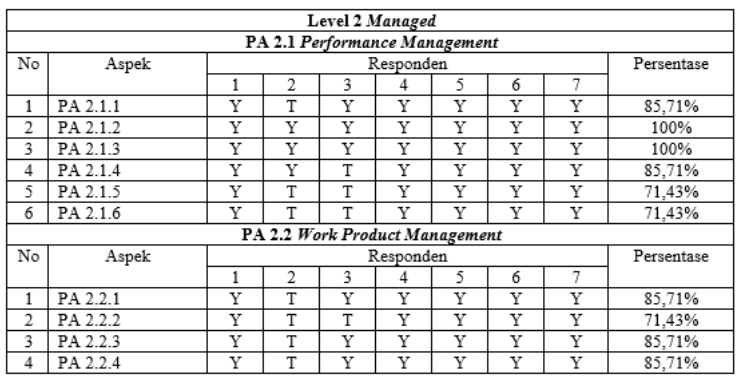

Pada tabel 5 menunjukan hasil dari pengukuran atribut level 2 pada domain BAI06. Rata-rata pencapaian pengukuran atribut level 2 pada PA 2.1 performance management adalah $85,71 \%$ dan PA 2.2 work product management adalah 82,14\% dengan rata-rata total mencapai $83,9 \%$. Berdasarkan rating levels pada tabel 3 level 2 pada domain BAI06 adalah PA 2.1 performance management termasuk dalam pencapaian F (Fully Achieved) dan PA 2.2 work product management termasuk dalam pencapaian L (Largely Achieved).

Tabel 6. Pengukuran atribut level 3 pada domain BAI06

\begin{tabular}{|c|c|c|c|c|c|c|c|c|c|}
\hline \multirow{2}{*}{\multicolumn{10}{|c|}{ Level 3 Established }} \\
\hline \multirow{3}{*}{ No } & \multicolumn{2}{|c|}{ PA 3.1 Process Definition } & & & & & & & \\
\hline & \multirow[t]{2}{*}{ Aspek } & \multicolumn{7}{|c|}{ Responden } & \multirow{2}{*}{ Persentase } \\
\hline & & 1 & 2 & 3 & 4 & 5 & 6 & 7 & \\
\hline 1 & PA 3.1 .1 & $\mathrm{Y}$ & $\mathrm{Y}$ & $\mathrm{T}$ & $\mathrm{Y}$ & $\mathrm{Y}$ & $\mathrm{Y}$ & $\mathrm{Y}$ & $85,71 \%$ \\
\hline 2 & PA 3.1.2 & $\mathrm{Y}$ & $\mathrm{T}$ & $\mathrm{T}$ & $\mathrm{Y}$ & $\mathrm{Y}$ & $\mathrm{Y}$ & $\mathrm{Y}$ & $71,43 \%$ \\
\hline 3 & PA 3.1.3 & $\mathrm{Y}$ & $\mathrm{T}$ & $\mathrm{Y}$ & $\mathrm{Y}$ & $\mathrm{Y}$ & $\mathrm{Y}$ & $\mathrm{Y}$ & $85,71 \%$ \\
\hline 4 & PA 3.1.4 & $\mathrm{Y}$ & $\mathrm{T}$ & $\mathrm{Y}$ & $\mathrm{Y}$ & $\mathrm{Y}$ & $\bar{Y}$ & $\mathrm{Y}$ & $85,71 \%$ \\
\hline 5 & PA 3.1.5 & $\mathrm{Y}$ & $\mathrm{T}$ & $\mathrm{Y}$ & $\mathrm{Y}$ & $\mathrm{Y}$ & $\mathrm{Y}$ & $\mathrm{Y}$ & $85,71 \%$ \\
\hline \multicolumn{10}{|c|}{ PA 3.2 Process Deployment } \\
\hline \multirow[t]{2}{*}{ No } & Aspek & \multicolumn{7}{|c|}{$\begin{array}{l}\text { Responden } \\
\end{array}$} & Persentase \\
\hline & & 1 & 2 & 3 & 4 & 5 & 6 & 7 & \\
\hline 1 & PA 3.2.1 & $\mathrm{Y}$ & $\mathrm{T}$ & $\mathrm{Y}$ & $\mathrm{Y}$ & $\mathrm{Y}$ & $\mathrm{Y}$ & $\mathrm{Y}$ & $85,71 \%$ \\
\hline 2 & PA 3.2.2 & $\mathrm{Y}$ & $\mathrm{Y}$ & $\mathrm{T}$ & $\mathrm{Y}$ & $\mathrm{Y}$ & $\overline{\mathrm{Y}}$ & $\mathrm{Y}$ & $85,71 \%$ \\
\hline 3 & PA 3.2.3 & $\mathrm{Y}$ & $\mathrm{T}$ & $\mathrm{Y}$ & $\mathrm{Y}$ & $\mathrm{Y}$ & $\mathrm{Y}$ & $\mathrm{Y}$ & $85,71 \%$ \\
\hline 4 & PA 3.2.4 & $\mathrm{Y}$ & $\mathrm{T}$ & $\mathrm{Y}$ & $\mathrm{Y}$ & $\mathrm{Y}$ & $\mathrm{Y}$ & $\mathrm{Y}$ & $85,71 \%$ \\
\hline 5 & PA 3.2 .5 & $\mathrm{Y}$ & $\mathrm{T}$ & $\mathrm{Y}$ & $\mathrm{Y}$ & $\mathrm{Y}$ & $\mathrm{Y}$ & $\mathrm{Y}$ & $85,71 \%$ \\
\hline 6 & PA 3.2.6 & $\mathrm{Y}$ & $\mathrm{T}$ & $\mathrm{T}$ & $\mathrm{Y}$ & $\mathrm{Y}$ & $\mathrm{Y}$ & $\mathrm{Y}$ & $71,43 \%$ \\
\hline
\end{tabular}

Pada tabel 6 menunjukan hasil dari pengukuran atribut level 3 pada domain BAI06. Rata-rata pencapaian pengukuran atribut level 3 pada PA 3.1 process definition adalah $82,85 \%$ dan PA 3.2 process deployment adalah $83,33 \%$ dengan rata-rata total mencapai $83,09 \%$. Berdasarkan rating levels pada tabel 3 level 3 pada domain BAI06 adalah PA 3.1 process definition dan PA 3.2 process deployment termasuk dalam pencapaian L (Largely Achieved).

Tabel 7. Pengukuran atribut level 4 pada domain BAI06

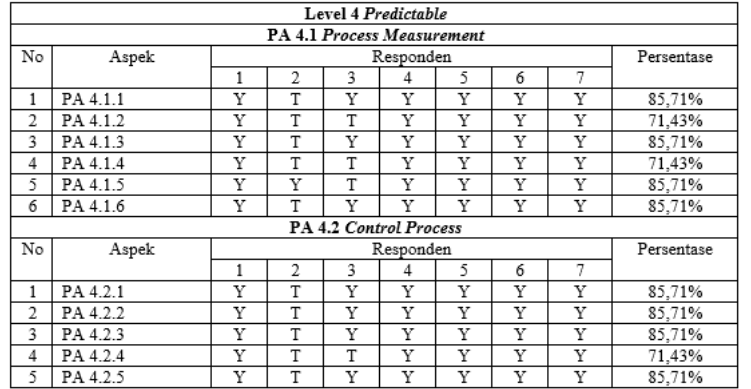

Pada tabel 7 menunjukan hasil dari pengukuran atribut level 4 pada domain BAI06. Rata-rata pencapaian pengukuran atribut level 4 pada PA 4.1 process measurement adalah $80,95 \%$ dan PA 4.2 control process adalah $82,85 \%$ dengan rata-rata total mencapai $81,9 \%$. Berdasarkan rating levels pada tabel 3 level 4 pada domain BAI06 adalah PA 4.1 process measurement dan PA 4.2 control process termasuk dalam pencapaian L (Largely Achieved).

Tabel 8. Pengukuran atribut level 5 pada domain

$$
\text { BAI06 }
$$

\begin{tabular}{|c|c|c|c|c|c|c|c|c|c|}
\hline \multicolumn{10}{|c|}{ Level 5 Optimizing } \\
\hline \multicolumn{10}{|c|}{ PA 5.1 Process Inovation } \\
\hline \multirow[t]{2}{*}{ No } & \multirow[t]{2}{*}{ Aspek } & \multicolumn{7}{|c|}{ Responden } & \multirow[t]{2}{*}{ Persentase } \\
\hline & & 1 & 2 & 3 & 4 & 5 & 6 & 7 & \\
\hline 1 & PA 5.1 .1 & $\mathrm{~T}$ & $\mathrm{Y}$ & $\mathrm{Y}$ & $\mathrm{T}$ & $\mathrm{T}$ & $\mathrm{Y}$ & $\mathrm{T}$ & $42,86 \%$ \\
\hline 2 & PA 5.1 .2 & $\mathrm{Y}$ & $\mathrm{T}$ & $\mathrm{T}$ & $\mathrm{Y}$ & $\mathrm{Y}$ & $\mathrm{Y}$ & $\mathrm{Y}$ & $71,43 \%$ \\
\hline 3 & PA 5.1.3 & $\mathrm{Y}$ & $\mathrm{T}$ & $\mathrm{Y}$ & $\mathrm{Y}$ & $\mathrm{Y}$ & $\mathrm{Y}$ & $\mathrm{Y}$ & $85,71 \%$ \\
\hline 4 & PA 5.1.4 & $\mathrm{Y}$ & $\mathrm{T}$ & $\mathrm{T}$ & $\mathrm{Y}$ & $\mathrm{Y}$ & $\mathrm{Y}$ & $\mathrm{Y}$ & $71,43 \%$ \\
\hline 5 & PA 5.1 .5 & $\mathrm{Y}$ & $\mathrm{Y}$ & $\mathrm{Y}$ & $\mathrm{Y}$ & $\mathrm{Y}$ & $\mathrm{Y}$ & $\mathrm{Y}$ & $100 \%$ \\
\hline \multicolumn{10}{|c|}{ PA 5.2 Process Optimisation } \\
\hline \multirow[t]{2}{*}{ No } & Aspek & \multicolumn{7}{|c|}{ Responden } & Persentase \\
\hline & & 1 & 2 & 3 & 4 & 5 & 6 & 7 & \\
\hline 1 & PA 5.2 .1 & $\mathrm{Y}$ & $\bar{Y}$ & $\mathrm{Y}$ & $\mathrm{Y}$ & $\mathrm{Y}$ & $\mathrm{Y}$ & $\mathrm{Y}$ & $100 \%$ \\
\hline 2 & PA 5.2 .2 & $\mathrm{Y}$ & $\mathrm{T}$ & $\mathrm{Y}$ & $\mathrm{Y}$ & $\mathrm{Y}$ & $\mathrm{Y}$ & $\mathrm{Y}$ & $85,71 \%$ \\
\hline 3 & PA 5.2 .3 & $\mathrm{Y}$ & $Y$ & $\mathrm{Y}$ & $\mathrm{Y}$ & $\mathrm{Y}$ & $\mathrm{Y}$ & $\mathrm{Y}$ & $100 \%$ \\
\hline
\end{tabular}

Pada tabel 8 menunjukan hasil dari pengukuran atribut level 5 pada domain BAI06. Rata-rata pencapaian pengukuran atribut level 5 pada PA 5.1 process inovation adalah $74,29 \%$ dan PA 5.2 process optimisation adalah $95,24 \%$ dengan rata-rata total mencapai $84,77 \%$. Berdasarkan rating levels pada tabel 3 level 5 pada domain BAI06 adalah PA 5.1 process inovation termasuk dalam pencapaian $\mathrm{L}$ (Largely Achieved) dan PA 5.2 process optimisation termasuk dalam pencapaian F (Fully Achieved).

Pengukuran tingkat kapabilitas didapatkan dari rekapitulasi hasil jawaban kuesioner tingkat kapabilitas pada proses BAI06. Hasil rekapitulasi pengukuran tingkat kapabilitas pada domain BAI06 yaitu level 1 mencapai $82,14 \%$, level 2 mencapai $83,9 \%$, level 3 mencapai $83,09 \%$, level 4 mencapai $81,9 \%$, dan level 5 mencapai $84,77 \%$. Hasil pengukuran tingkat kapabilitas pada domain BAI06 (manage changes) berada pada level 1 (performed process) yang ditunjukan pada tabel 9 berikut ini.

Tabel 9. Daftar rekapitulasi kuesioner BAI06

\begin{tabular}{|l|c|c|c|c|c|c|c|c|c|c|}
\hline $\begin{array}{l}\text { Process } \\
\text { Name }\end{array}$ & $\begin{array}{c}\text { Level } \\
0\end{array}$ & $\begin{array}{c}\text { Level } \\
1\end{array}$ & \multicolumn{2}{|c|}{ Level 2 } & \multicolumn{2}{|c|}{ Level 3 } & \multicolumn{2}{c|}{ Level 4 } & \multicolumn{2}{|c|}{ Leve1 5 } \\
\hline BAI06 & & PA & PA & PA & PA & PA & PA & PA & PA & PA \\
& & 1.1 & 2.1 & 2.2 & 3.1 & 3.2 & 4.1 & 4.2 & 5.1 & 5.2 \\
\hline $\begin{array}{l}\text { Rating by } \\
\text { Criteria }\end{array}$ & & L & F & L & L & L & L & L & L & F \\
\hline $\begin{array}{l}\text { Capability } \\
\text { Level } \\
\text { Achieved }\end{array}$ & & 1 & \multicolumn{1}{|c|}{} & & & & & & & \\
\hline
\end{tabular}




\section{Jurnal Teknologi Informasi Dan Komunikasi, ISSN : 2087-0868, Volume}

11 Nomor 2 September 2020, Pengukuran Tingkat Kapabilitas Tata Kelola Infrastruktur

Teknologi Informasi Menggunakan Kerangka Kerja COBIT 5 Dan ITIL V.3

\subsection{Kondisi Harapan Pengukuran Tingkat Kapabilitas Tata Kelola Infrastruktur Teknologi Informasi Muhammadiyah Boarding School Yogyakarta}

Kondisi harapan merupakan kondisi untuk mengetahui harapan dari MBS (Muhammadiyah Boarding School) Yogyakarta dalam pencapaian tingkat kapabilitas tata kelola infrastruktur teknologi informasi. Pengukuran tingkat kapabilitas kondisi harapan seperti pada pengukuran tingkat kapabilitas kondisi saat ini yaitu berupa kuesioner yang diisi oleh responden dan menggunakan skala pengukuran pemenuhan kriteria berdasarkan atribut proses. Tabel hasil pengukuran kondisi harapan pada domain BAI06 (manage changes) dapat dilihat pada tabel 10 berikut ini.

Tabel 10. Kondisi harapan pada domain BAI06

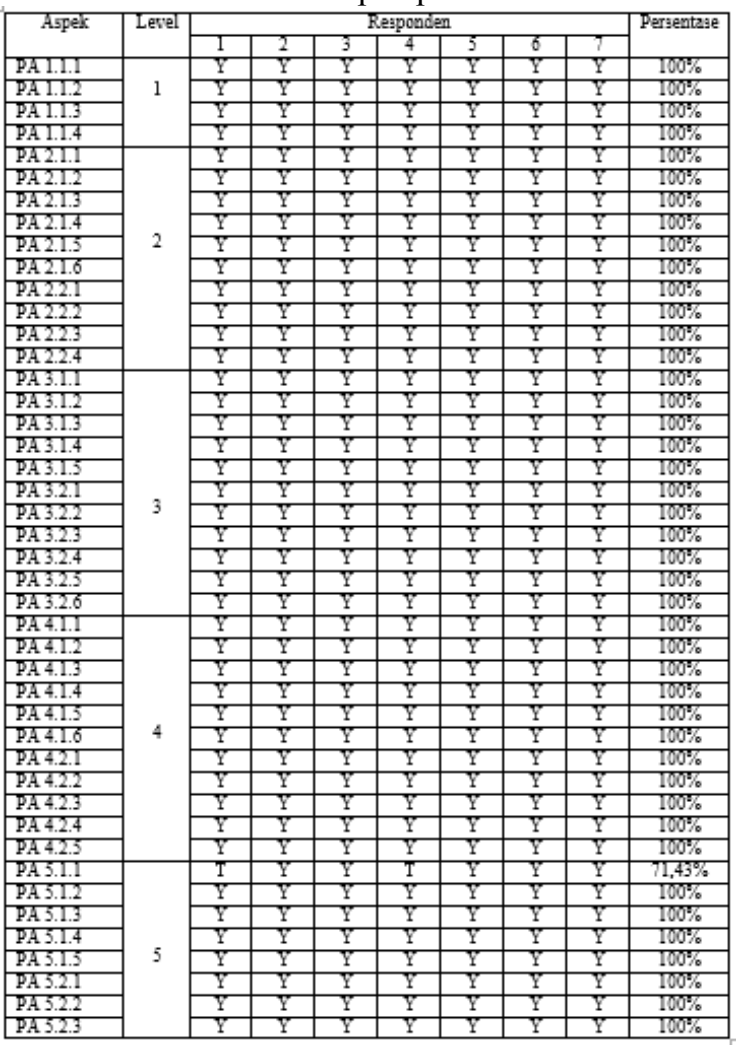

Berdasarkan tabel 10 kondisi harapan pada domain BAI06 didapatkan pencapaian pada level 1 mencapai $100 \%$, level 2 mencapai $100 \%$, level 3 mencapai $100 \%$, level 4 mencapai $100 \%$, dan level 5 mencapai 97,15\% (jumlah rata-rata dari PA 5.1 sebesar 94,29\% dan PA 5.2 sebesar 100\%). Hasil pencapaian kondisi harapan pada level 1 sampai 5 berdasarkan rating levels pada tabel 3 termasuk dalam pencapaian F (Fully Achieved). Pengukuran tingkat kapabilitas kondisi harapan pada domain BAI06 berada pada level 5 .

\subsection{Analisis GAP}

Analisis gap digunakan untuk mentukan kesenjangan kondisi saat ini dengan kondisi yang diharapkan. Berdasarkan kesenjangan yang terjadi dilakukan perbaikan aspek-aspek untuk mencapai kondisi yang diharapkan. Domain BAI06 (manage changes) yaitu mengelola permintaan perubahaan pada MBS (Muhammadiyah Boarding School) Yogyakarta. Hasil pengukuran tingkat kapabilitas Muhammadiyah Boarding School Yogyakarta pada kondisi saat ini berada pada level 1, sedangkan harapan yang ingin dicapai berada pada level 5 .

Berdasarkan pengukuran tersebut terjadi kesenjangan 4 level sehingga perlu dilakukan perbaikan dan pengembangan aspek yang belum dipenuhi. Aspek yang belum terpenuhi yaitu pada poin PA 5.1.1 yaitu dokumentasi petunjuk pengelolaan inovasi teknologi informasi dan perbaikannya untuk mendukung tujuan bisnis dengan persentase pemenuhan $42,86 \%$.

Aspek PA 3.1.2 yaitu skema integrasi proses mencapai persentase pemenuhan $71,43 \%$, akan tetapi berdasarkan hasil observasi belum terpenuhi dikarenakan di MBS (Muhammadiyah Boarding School) Yogyakarta pada saat melakukan manajemen perubahan berdasarkan kepada keputusan dari masing-masing divisi sehingga bersifat parsial dan tidak terintegrasi dengan divisi lainnya. Aspek PA 1.1.2 yaitu mengelola perubahan darurat mencapai persentase $71,43 \%$, akan tetapi berdasarkan hasil observasi pada saat terjadi manajemen perubahan yang sifatnya darurat Muhammadiyah Boarding School Yogyakarta belum menerapkan pengelolaan perubahan darurat teknologi informasi. Dokumentasi yang terdapat pada pengelolaan perubahan darurat teknologi informasi dapat menjadi petunjuk bagi setiap pemangku kepentingan sehingga diperlukan suatu prosedur perubahan darurat teknologi informasi untuk meminimalkan insiden yang terjadi.

\subsection{Saran Pengembangan}

Pengukuran tingkat kapabilitas menggunakan COBIT 5 mengacu kepada standar ISO/IEC 15504 (ISACA, 2012) dan ITIL V3 juga mengacu kepada standar ISO/IEC 15504 (SPICE, 2010). Jadi pengukuran tingkat kapabilitas menggunakan COBIT 5 kompatibel dengan ITIL V3.

Berdasarkan analisis gap diketahui bahwa aspek yang perlu diperbaiki maupun dikembangkan yaitu terkait dengan proses manajemen perubahan teknologi informasi, pengelolaan perubahan darurat teknologi informasi, integrasi proses perubahan, dan pengelolaan inovasi teknologi informasi. Saran perbaikan dan pengembangan aspek-aspek tersebut dibuat berdasarkan kerangka kerja ITIL V3. 


\section{Jurnal Teknologi Informasi Dan Komunikasi, ISSN : 2087-0868, Volume}

11 Nomor 2 September 2020, Pengukuran Tingkat Kapabilitas Tata Kelola Infrastruktur Teknologi Informasi Menggunakan Kerangka Kerja COBIT 5 Dan ITIL V.3

Saran-saran yang dapat diberikan untuk mencapai kondisi yang diharapkan pada tata kelola infrastruktur teknologi informasi di MBS (Muhammadiyah Boarding School) Yogyakarta antara lain sebagai berikut.

1. Perlunya dokumentasi petunjuk pengelolaan inovasi teknologi informasi dan perbaikannya untuk mendukung tujuan bisnis.

2. Melakukan koordinasi dalam melakukan pengambilan keputusan antar divisi terkait dengan perubahan teknologi informasi sehingga tidak bersifat parsial pada saat terjadi manajemen perubahan teknologi informasi.

3. Menerapkan pengelolaan perubahan darurat teknologi informasi agar dapat menjadi petunjuk saat terjadi perubahan darurat sehingga meminimalkan insiden yang terjadi.

\section{Kesimpulan}

Kesimpulan dari penelitian ini antara lain sebagai berikut.

1. Hasil pengukuran tingkat kapabilitas tata kelola infrastruktur teknologi informasi pada domain BAI06 (manage changes) berada pada level 1 (performed process).

2. Hasil pengukuran kondisi harapan tingkat kapabilitas Muhammadiyah Boarding School Yogyakarta pada domain BAI06 berada pada level 5

3. Berdasarkan pengukuran tingkat kapabilitas terdapat gap 4 level antara kondisi saat ini dan kondisi yang diharapkan. Ada beberapa aspek yang perlu diperbaiki maupun dikembangkan yaitu terkait dengan proses manajemen perubahan teknologi informasi, pengelolaan perubahan darurat teknologi informasi, integrasi proses perubahan, dan pengelolaan inovasi teknologi informasi.

4. Saran-saran yang dapat diberikan untuk mencapai kondisi yang diharapkan pada tata kelola infrastruktur teknologi informasi di Muhammadiyah Boarding School Yogyakarta antara lain sebagai berikut.

a. Perlunya dokumentasi petunjuk pengelolaan inovasi teknologi informasi dan perbaikannya untuk mendukung tujuan bisnis.

b. Melakukan koordinasi dalam melakukan pengambilan keputusan antar divisi terkait dengan perubahan teknologi informasi sehingga tidak bersifat parsial pada saat terjadi manajemen perubahan teknologi informasi. c. Menerapkan pengelolaan perubahaan darurat teknologi informasi agar dapat menjadi petunjuk saat terjadi perubahan darurat sehingga meminimalkan insiden yang terjadi.

\section{Ucapan Terima Kasih}

Ucapan terima kasih Penulis diberikan kepada kementerian riset teknologi/badan riset dan inovasi nasional republik Indonesia yang telah memberikan hibah penelitian dosen pemula.

\section{Daftar Pustaka}

Ali S. Green P. 2012. Effective information technology (IT) governance mechanisms: An IT outsourcing perspective. Springer. 14 (2): 179-193

Anas, Syukron; Wing Wahyu Winarno; Hanif Al Fatta.,2017, Evaluasi Tata Kelola Teknologi Informasi Akademik STMIK Dipanegara Makassar, Jurnal PPKM I, ISSN:2354-869X, 2017.

Fryonanda, Herfebi.,2017, Evaluasi Tata Kelola Infrastruktur Teknologi Informasi IPB dengan Framework COBIT 5 dan ITIL V3 2011, Institut Pertanian Bogor.

Hartawan, Firman; Jarot S. Suroso., 2017, Information Technology Service Evaluation Based ITIL V3 2011 and COBIT 5 in Center for Data and Information, Asian Conference on Intelligent Information and Database Systems, Kanazawa, Jepang, 2017

HM, Jogiyanto., dan Willy Abdillah. 2011, Sistem Tatakelola Teknologi Informasi, Andi, Yogyakarta.

ISACA, COBIT 5 : A Business Framework for the Governance and Management of Enterprise IT. USA: ISACA, 2012.

ISACA, COBIT 5 : Enabling Processes. USA: ISACA, 2012.

Motii, Malik; Alami Semma.,2017, Towards a New Approach to Pooling COBIT 5 and ITIL V3 with ISO/IEC 27002 for Better Use of ITG in the Moroccan Parliament, International Journal of Computer Science Issues, Vol 14, ISSN : 16940784, May 2017.

Noorhasanah; Wing Wahyu Winarno; Dani Adhipta.,2015, Evaluasi Tata Kelola Teknologi Informasi Berbasis Framework COBIT 5, Seminar 
Jurnal Teknologi Informasi Dan Komunikasi, ISSN : 2087-0868, Volume 11 Nomor 2 September 2020, Pengukuran Tingkat Kapabilitas Tata Kelola Infrastruktur Teknologi Informasi Menggunakan Kerangka Kerja COBIT 5 Dan ITIL V.3

Nasional Teknologi Informasi dan Multimedia, ISSN:2302-3805, Yogyakarta, 6-8 Februari 2015.

Purnomo, Heri; Silmi Fauziati; Wing Wahyu Winarno., 2016, Penilaian Tingkat Kapabilitas Proses Tata Kelola Teknologi Informasi dengan COBIT 5 pada Domain EDM (Studi Kasus di PT. Nusa Halmahera Minerals), Konferensi Nasional Teknologi Informasi dan Komunikasi (KNASTIK), ISSN: 2338-7718, Yogyakarta, 2016.

Retrialisca, Fitri.,2017, Pengukuran Kesuksesan Sistem Informasi Berdasarkan D\&M Model dan COBIT 5 (Studi Kasus Universitas Airlangga), Magister Teknologi Informasi, Institut Teknologi Sepuluh November, Surabaya.

Riedel M; Streit A; Wolf F; Lippert T; Kranzlmuller D.,2008, Classification of different approaches for escience applications in next generation computing infrastructures, IEEE Fourth International Conference on eScience, Piscataway (US), 7-12 Desember 2008.

Robertson B, Sribar V. 2001. The Adaptive Enterprise: IT Infrastructure Strategies to Manage Change and Enable Growth. Hillsboro (GD): Intel Press.

Simotakis, Michalis.,2013, Integrating ITIL and COBIT 5 to Optimize IT Process and Service Delivery, ITSMF South East Europe Conference, Athens, Greece, 19 April 2013.

SPICE (2010). Enterprise SPICE : An Integrated Model for Enterprise-wide Assessment and Improvement. Available online: www.enterprisespice.com.

Stake, Robert E., (2006). The Art of Case Study. London: Sage Publications, Inc.

Sudaryono, 2015, Metodologi Riset di Bidang TI (Panduan Praktis, Teori, dan Contoh Kasus), Penerbit Andi, Yogyakarta.

Surendro, Krisdanto., 2009, Implementasi Tata Kelola Teknologi Informasi, Informatika, Bandung.

Weill, P., dan Ross, J.2004, IT Governance: How Top Performers Manage IT Decision Rights for Superior Result, Harvard Business School Press, Boston. 